\title{
Historical traces and perspectival possibilities of traditional camel keeping in Carpathian Basin
}

\author{
Andras Halasz ${ }^{1 *}$, Istvan Csizi $^{2}$ and Arpad Kenez ${ }^{3}$
}

\begin{abstract}
In this paper we have gathered and put into context all accessible sources regarding one-hump (dromedaryCamelus dromedarius) or two-hump Bactrian camels (Camelus bactrianus) in the Carpathian Basin. Reviewed sources and empirical statements have pointed out the growing European demand for camel meat and milk. These species are capable of grazing overexploited and bush-encroached pastures, besides producing valuable fibre in the form of camel hair, and be used in the tourism business as well. Because of anatomical and physiological adaptations, both species are capable of digesting rough fibre and vegetation unused by other livestock species. Therefore, camels are the ideal choice for pasture rehabilitation, especially in shrublands and overgrown areas. Both species are flexible browsers in extensive grazing systems due to their adaptation to steppe regions. Dromedaries are more suited to dry hot ecosystems while Bactrian camels are more adapted to a cold and wetter environment.

Dromedary and Bactrian camel cross-breeding practices present modern solutions for introducing these species into pasture-based livestock farming. Dromedary genetic dominance increases milk production with lower milk fat. Bactrian genes deliver higher wool production and more resilient calves. Beyond the agricultural and conservation functions, the ethnographical and cultural roles are also important in Hungarian folklore.
\end{abstract}

Keywords: Steppe, Shrub control, Ruderal vegetation, Pasture preparation

\section{Introduction}

In this article, the authors intend to present a summary about the historical traces (Daróczi-Szabó et al., 2014; Biller, 2017) and current perspectival exploitation possibilities of Bactrian camels and their hybrids according to the available scientific sources and empirical standpoints (Fig. 1). Upon looking at the natural spread of camel species, the research conducted by Szalay (1918) and Ortvay (1902) reveal that in the quaternary, camel species reached the Dinaric Mountains along the subDanube. There are speculations about camel-keeping in Carpathian Basin (Bartosiewicz 1996), as the conquering Hungarians possibly used Bactrian camel as beasts of

\footnotetext{
* Correspondence: halasz.andras@uni-mate.hu

${ }^{1}$ Hungarian University of Agriculture and Life Sciences, Godollo campus,

Pater K. str. 1, Godollo 2100, Hungary

Full list of author information is available at the end of the article
}

burden. Wenzel (1887) was the first to express that "in the era of chiefs and under the reign of early kings, camels were mostly used as beasts of burden, but it seems that by the $13^{\text {th }}$ Century they mostly disappeared from the stock of domestic animals". In middle-age Hungary, the scientific public sphere does not take an obvious stand concerning the spread of either the dromedary (Camelus dromedarius) nor the Bactrian camel (Camelus bactrianus) species. Although most of the renowned researchers (Rómer, Hahn) doubted the domestic presence of camels, Ritter (1847) still theorized that by the Hun invasion they reached the Carpathian Basin. Ortvay (1902) emphasizes that the eastern tribes of Pechenegs and Cumans, among others, brought camels with them upon settling down in the Árpád-era, thus "giving an oriental character to the household of our ancestors". Upon observing the picture depicting the 


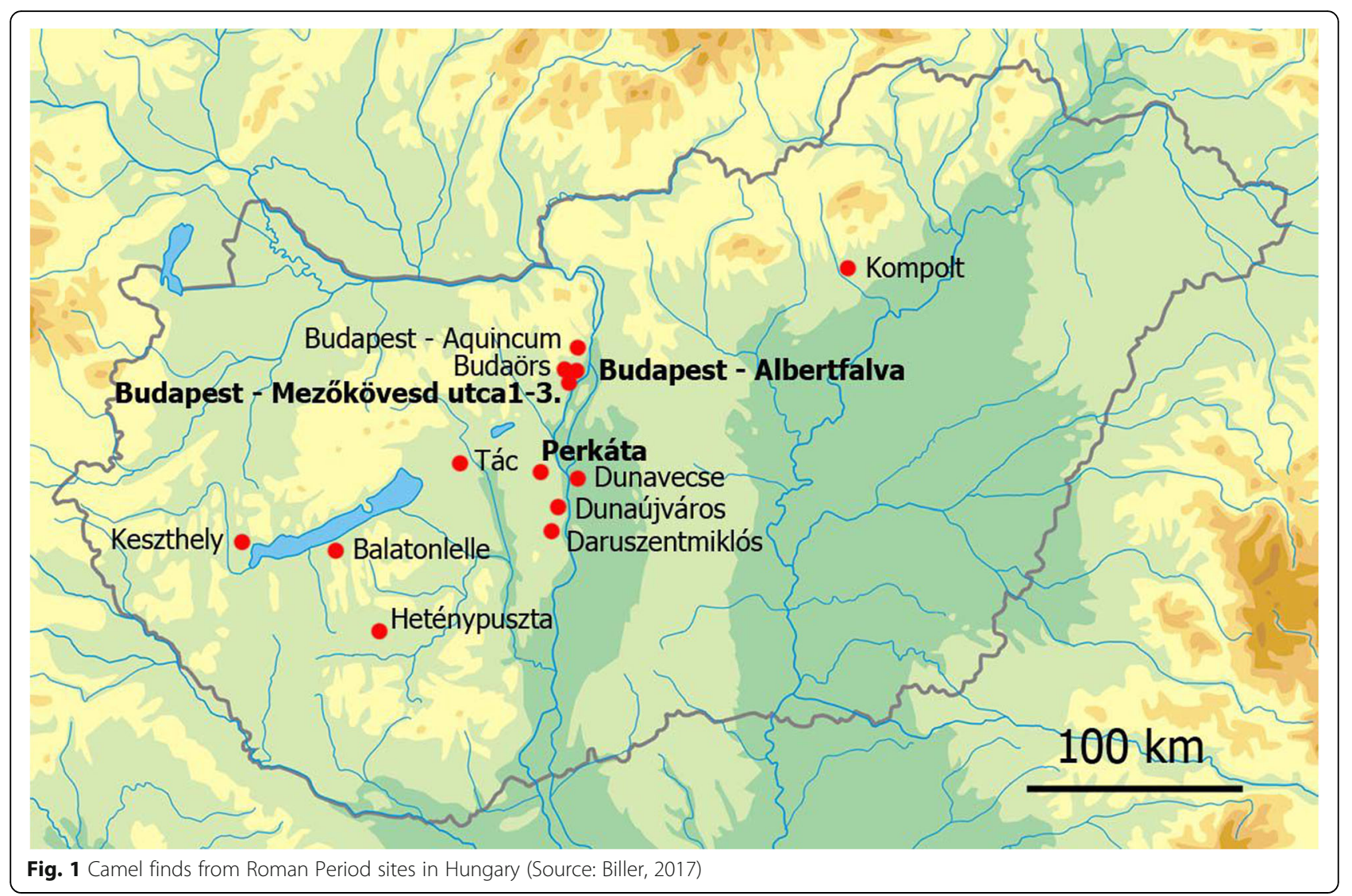

Hungarian conquest in the Vienna Illuminated Chronicle-Chronicon Pictum (1358) (Fig. 2), besides horses, the presence of camels is also evident in the illustrations.

It is also reinforced by Darkó's (1915) dissertation about the military treatise of Leo VI The Wise (Tacticon), stating that "The Turks are followed by a huge number of cattle, horse and beasts of burden, partly in order to provide food and milk to drink, and partly to make their numbers look greater." Gyula László (1944) cites an authentic contemporary source, stating that our king, Béla III, presented the crusaders passing by, among others, with load-bearing camels, to secure their crossing over the Syrian Desert. Szalay's (1918) opinion is that although it cannot be declared hundred percent that a greater number of camels would have appeared in Hungary either in domesticated or in wild form, still "it is much more plausible and natural that the Hungarians brought camels with them in the $9^{\text {th }}$ Century, from the East, a region where they certainly bred, than stating that 300 years later they suddenly had an idea to import camels". An interesting addition is that in the thirteenth century, Friar Julian found Magna Hungaria (mentioned in Riccardus' report 1237) with its Hungarian inhabitants in Bactria (Dörrie 1956; Nagy et al. 2020; NET 1).
It is almost certain that upon the Hungarian conquest/ immigration, camels accompanied the army and the settlers and were bred for approximately further 300 years, to be finally swept away by the progress of transportation. Dioli $(2014,2015)$ states the possibility that dromedary and Bactrian camels were used for cross-breeding to provide more resilient and high-yielding milking hybrids. They have as much legal basis to be considered indigenous, as the "cikta" sheep, carried on rafts and settled in by the Kraut settlers of the eighteenth century.

On top of that, it stands out from the works of the palaeontologists Kubinyi (1859) and Kretzol (1953, 1959) that camels (Camelus cf. bessarabiensis, Khomenko) appeared in the Carpathian Basin long before the Hungarian conquest, in the lower Pleistocene ages (Kretzol 1953). During the excavation of the Calabrian fauna at Kisláng, it became evident that "by accepting certain oriental influences (camel, ostrich, Lagurus), and at the same time secluding some particular western impacts (Hippopotamus, certain hyenas, etc.) the Hungarian Basin shows definite faunal endemity" (Kretzol 1953).

The presence of dromedaries and camel hybrids as important beasts of burden during military campaigns in the Hungarian regions of the Ottoman Empire is a well- 

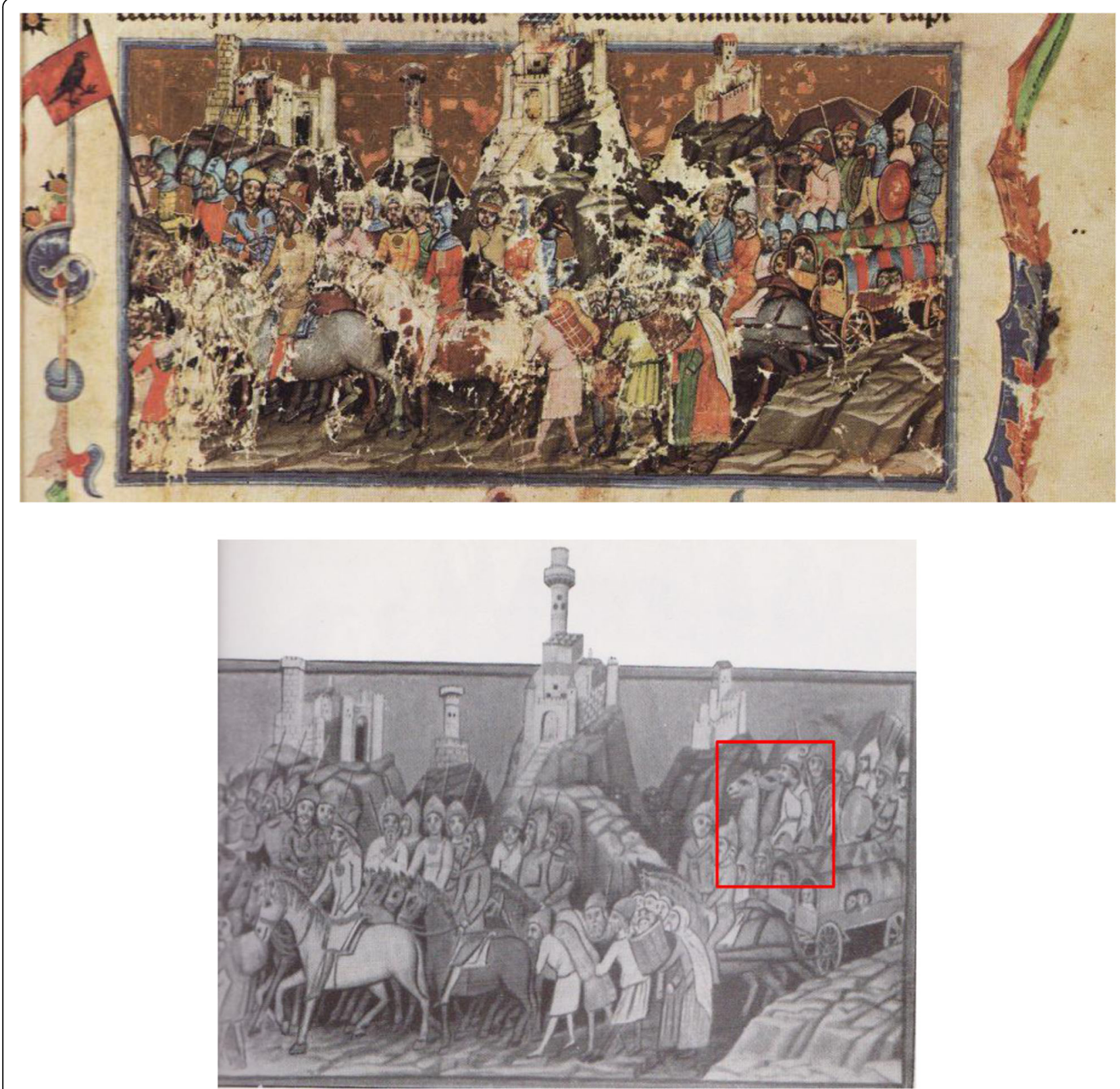

Fig. 2 Immigration of Huns to Pannonia-Primus ingressus Hungarorum in Pannoniam (National Szechenyi Library)

known axiom (NET 2). Even in WWI, Hungarian troops took advantage of the "ship of desert" (Fig. 3).

\section{Housing and foraging}

The continental climate is not ideal for dromedary but more suitable for Bactrian camels. The Turkish research still focus on these animals, especially hybrids, because of their wide tolerance to hostile weather and mountainous terrain (Dioli 2018a; NET 3). Housing systems depend on utilization. Milk-producing dromedaries, based on intensive housing systems, require as much attention than any intensive dairy cow. Ventilated sheds, adequate amount of water, and quality fodder are a must for the daily 10-15 l of milk production. Bactrians and dromedaries can be kept as beef cattle with minimal housing, wind protection, and plenty of roughages. Extremely low temperature is tolerable for Bactrians if dry spots are present.

They require high-fibre forage based on woody plants. Fibre digestion correlates with the available protein (Kamalu et al. 2010). Camels also need ad libitum salt supplementation or to graze pastures of salty plants (Dioli 2018b; NET 4). Salt has positive effects on dry matter intake (Johansson 2008) and 


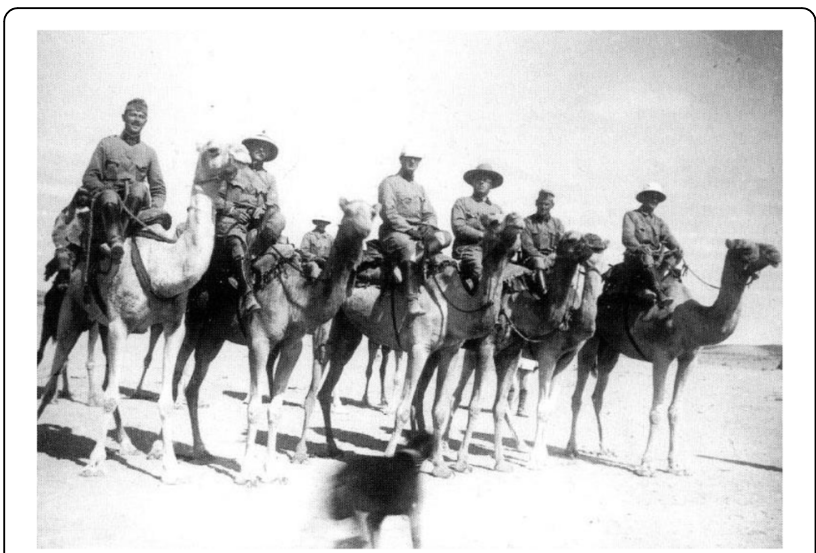

Fig. 3 Austro-Hungarian troops in Holy Land 1916-1918. Reconnaissance riding in the desert

(source: http://riowang.blogspot.com/2010/07/our-troops-standingat-gaza.html)

provides solid digested fibre and energy for milk production.

\section{Camel milk}

According to Fábri et al. (2014) lactation production could reach 90001 in 10 months. Diversification in the dairy industry is a key factor for growth; therefore, an exotic milk source could be a flagship industry. Solids in camel milk are remarkable especially in fat and sugar (Table 1). Dairy processors' mid-term strategy is to investigate the potential growth in dairy products. Because of the lack of $\beta$-casein there are no allergic reactions and it is easy to digest for children, since dromedary milk is very similar to human milk (Zibaee et al. 2015). The lactoferrin content is a bactericide which is the strongest within mammals (Bíró 2014). Camel milk contains high level of Vitamin $\mathrm{C}$ and is also used in lactose intolerance diets (Fábri et al. 2014).

\section{Camel meat}

Camel meat products are unique on the market. There is a strong potential for reformed and healthy food gastronomy due to the low cholesterol level (Table 2) (Dublecz 2011; Hussein 2018).

Table 2 Meat compounds of different species (average values)

\begin{tabular}{|c|c|c|c|c|c|}
\hline \multirow[b]{2}{*}{ Species } & \multicolumn{3}{|c|}{$\mathrm{g} / 100 \mathrm{~g}$} & \multirow{2}{*}{$\frac{\mathrm{mg} / 100 \mathrm{~g}}{\text { Cholesterol }}$} & \multirow{2}{*}{$\frac{\mathrm{kJ} / 100 \mathrm{~g}}{\text { Energy }}$} \\
\hline & Water & Protein & Fat & & \\
\hline Camel & 78 & 19.8 & 1.17 & 59 & 1117 \\
\hline Beef & 74 & 20.3 & 4.6 & 86 & 515 \\
\hline Pork & 72 & 20.7 & 7.1 & 86 & 625 \\
\hline Lamb & 70 & 20.8 & 8.8 & 99 & 678 \\
\hline Chicken & 74 & 20.5 & 4.3 & 89 & 506 \\
\hline
\end{tabular}

\section{Camel hair and leather}

The camel hair is similar to sheep wool. There are white Bactrian camels with valuable fine wool. Mongolian craftsmen make clothing, ropes, bridles, and tethers from camel hair. It is so flexible that mixed wool gains extra tensile strength (Czeglédy 2020). In the eighteenth century, Hungarian merchants' outfits had camel hair accessories (belts, pelisse, dolman) (Zoltai 1938; NET 5). The word 'camelot' (hun - csömölet) derived from the word 'camel', means shiny, whisked clothing. This is also a synonym of 'kamuka', 'camoca' (NET 6).

There is a Hungarian industrial connection with camel leather as Kazakh imports were at the peak during the 1980s; therefore, a group of microbiologists got the opportunity to grow de-hairing bacteria (Rozs 2001). Since then, it is a trademark in Szeged University, Hungary.

Other interesting utilization methods of camlet or cameline (NET 7) are:

- St. John the Baptist has worn rough camel hair clothing.

- Acari repellant effectivity was measured by a camel brush test (Bleicher 2003).

- In older vehicles, the clutch discs were covered with camel hair (Lestyán 2006).

- In WWII airmens' high altitude protective clothing was made from camel hair (Reszegi 2017).

\section{Discussion}

An evident question is why would Hungary need Bactrian camels, why would it need to be classified as an indigenous (NET 8), protected, or perhaps as an economic species receiving additional support? In order to illustrate the contemporary significance of Bactrian camels, we cite some facts from the verbal information from József Farkas, an inhabitant of Karcag. József Farkas had the opportunity to keep camels between 1944 and 1946. In the fall of 1944, the Russian soldiers invading his farm took his horse carriage, but in exchange, they left their single-axle carriage pulled by a male and a female

Table 1 Milk nutrient content of different species (average values) (Csapó and Salamon 2018)

\begin{tabular}{|c|c|c|c|c|c|}
\hline \multirow[b]{2}{*}{ Species } & \multicolumn{3}{|c|}{$\mathrm{g} / 100 \mathrm{~g}$} & \multirow{2}{*}{$\begin{array}{l}\mathrm{kJ} / 100 \mathrm{~g} \\
\text { Energy }\end{array}$} & \multirow{2}{*}{$\begin{array}{l}\mathrm{mg} / 100 \mathrm{~g} \\
\text { Calcium }\end{array}$} \\
\hline & Fat & Protein & Sugar & & \\
\hline Camel & 4.1 & 2 & 4.7 & 264 & 94 \\
\hline Cow & 3.9 & 3.2 & 4.6 & 276 & 115 \\
\hline Goat & 3.5 & 3.1 & 4.4 & 253 & 100 \\
\hline Sheep & 6 & 5.4 & 5.1 & 396 & 170 \\
\hline Buffalo & 8.4 & 3.95 & 4.8 & 385 & 175 \\
\hline Horse & 1.2 & 2 & 5.8 & 176 & 100 \\
\hline Human & 4.1 & 1.3 & 7.2 & 289 & 34 \\
\hline
\end{tabular}


Bactrian camel. He used the camel-driven carriage for earthwork and transportation on a daily basis. A young female camel was also born before the Russians, temporarily leaving the country, confiscated this carriage too. The most interesting part of his report concerning pasture management was when he gave an account about the feeding habits of the camels. The camels he was taking care of fed at the outskirts of the city, in the messy areas covered with thorny briars, thoroughly consuming the briar twigs, leaving only a white torso unable to sprout. They did the same with the newly sprung young sprouts. They almost exclusively consumed these bush twigs, despite the availability of the plentiful dense grass in the area. At the same time, the previously repressed grass stocks strengthened in place of the consumed briar scrub, providing a rich pasture for the next year. None of our domestic economic species, not even goats, are capable of such biological weeding. As in our country, the natural closing successions of grassy meadows consist of scrubs and forests, looking at the growing domestic rate of unused grass fields, this re-cultivation opportunity for scrubby pastures could be worth considering. The capability of the camels to "open up" dense bush by browsing on shrubs and trees has been noted before. This article tries to expand on this concept utilizing more literature (NET 9; Box et al. 2016).

\section{Conclusion}

In conclusion, we would like to emphasize that our primary concern is the problem of scrubby, abandoned pastures, where the phytomass of thorny scrubs forsaken by both men and animals and the dry grass in between act as potential timed fire sources. The utilization of Bactrian camels, as an ecological tool to control grazing areas overtaken by bush and shrubs on pastures, would not mean any competition for grass-based livestock (cattle, sheep), when grasses, shrubs, and forbs grow in the same region (Yagil 1982). In fact, they would act as "shrub-destroyers", creating productive pastures.

The growing number of people following the Islamic faith in the EU could prognostically provide a market for camel meat and milk being the by-products (Dioli, 2020) of camel breeding. Although camel slaughter is done differently than other ruminants, some modifications will have to be made to slaughterhouses. Also, Bactrians' milk yield is so low that in places like Kazakhstan and Turkmenistan, they are regularly crossed with dromedaries to increase milk production. Camel keeping could also diversify our touristic opportunities as ecological trekking animals in relevant Hungarian wild areas. This animal species could be a beneficiary of the increasing climate change if their breeding would be seriously considered. The provision of indigenous protection, which we consider as a reasonable step, could provide a strong initiating push in this direction. Camel herds present in EU countries (Netherlands, Germany) and importing Bactrian camels from Russia, Kazakhstan, and Turkmenistan also feasible options. The re-established herd should be concentrating on improved "breeds" like the Kalmyk and Arvana dromedary breed which is resistant to cold and wet conditions. If milk production is going to be a priority, it will be necessary to develop a hybridization plan. Ensuring the success of Bactrian camel reintroduction and utilization as a bush control livestock, it would be necessary to establish a reasonable experimental herd and to select an adequate grazing area that could be monitored.

\section{Supplementary Information}

The online version contains supplementary material available at https://doi. org/10.1186/s13570-021-00200-w.

\section{Additional file 1.}

Additional file 2.

Acknowledgements

We appreciate the valuable support of Zsuzsanna Borovka and David Mezoszentgyorgyi. Without their support, this paper would be less informative and relevant.

\section{Authors' contributions}

$\mathrm{AH}$ gathered the relevant literature and carried out the editing, ICS pointed out the problem with ruderal areas, and AK gathered the detailed dataset for milk and meat production. All authors read and approved the final manuscript

\section{Funding}

Not applicable.

Availability of data and materials

The datasets used and/or analysed during the current study are available from the corresponding author on reasonable request.

\section{Declarations}

Ethics approval and consent to participate Not applicable.

Consent for publication

Not applicable.

\section{Competing interests}

The authors declare that they have no competing interests.

\section{Author details \\ ${ }^{1}$ Hungarian University of Agriculture and Life Sciences, Godollo campus, Pater K. str. 1, Godollo 2100, Hungary. ${ }^{2}$ Hungarian University of Agriculture and Life Sciences, Research Institute Karcag, Karcag, Hungary. ${ }^{3}$ Livestock Performance Testing Ltd., Godollo, Hungary.}

Received: 10 February 2021 Accepted: 28 April 2021

Published online: 07 September 2021

\section{References}

Bartosiewicz, L. 1996. Camels in antiquity: The Hungarian connection. Antiquity 70 (268): 447-453 https://doi.org/10.1017/S0003598X00083435.

Biller, A.Zs. 2017. Három újabb római kori teve (Camelus Linné 1758) lelet Magyaroroszágról. Archeometriai Mühely 2017/XIV/1.

Bíró, G. 2014. Élelmiszer-higiénia. Agroinform Kiadó. 
Bleicher, E. 2003. Akaricidek tesztelésének komplex módszere laboratóriumban. Doktori értekezés. Gödöllő: SZIE.

Box, J., B. Nano, C.E.M. Mc Burnie, G. Waller, D.M. McConnell, K. Brock, C. Paltridge, R.M. McGilvray, A. Bubb, and A.G. Edwards. 2016. The impact of feral camels (Camelus dromedarius) on woody vegetation in arid Australia. The Rangeland Journal 38 (2): 181 https://doi.org/10.1071/RJ15073.

Csapó, K., and Sz Salamon. 2018. A kanca kolosztrumának és tejének összetétele. Irodalmi összefoglaló. Tejgazdaság, LXXV. évfolyam, 2018/1. szám.

Czeglédy, P.P. 2020. Egy elveszett ruha nyomában. A föpapi ruha kritikai vizsgálata a ránk maradt szövegek és régészeti leletek fényében. Doktori disszertáció. Debrecen: Debreceni Református Hittudományi Egyetem.

Darkó, Jenő. 1915. Bölcs Leó Taktikájának hitelessége XVIII. fejezet. Értekezések a nyelv- és széptudományok köréböl. (szerk. Szinnyei). Budapest: XXIII. kötet 4.sz., MTA-kiadvány.

Daróczi-Szabó, L., M. Daróczi-Szabó, Zs.E. Kovács, A. Kőrösi, and B. Tugya. 2014. Recent camel finds from Hungary. Anthropozoologica 49 (2): 265-280.

Dioli, M. 2014. The missing hump: A clarification on the reported two-humped stage in the embryonic development of the dromedary (Camelus dromedarius). Journal of Camel Practice and Research 21 (2): 121-125 https:// doi.org/10.5958/2277-8934.2014.00023.X.

Dioli, M. 2015. A brief history of the breeding of the camel (Camelus dromedarius) in Italy. The $3^{\text {rd }}$ International Camel Conference at SOAS, 9-10 May 2015, School of Oriental and African Studies, University of London, UK.

Dioli, M. 2018a. Camels in Europe: A brief history of camel hybrids and camel breeding in Europe over the last 1000 years. Second International SelçukEphesus Symposium on Culture of Camel-Dealing and Camel Wrestling. 1819-20 January 2018, Selçuk/lzmir/Turkey.

Dioli, M. 2018b. How much, how often and in which form should salt (NaCl) be given to a camel? The $5^{\text {th }}$ Conference of the International Society of Camelid Research and Development. Laâyoune, Morocco: 12 $2^{\text {th }}-15^{\text {th }}$ November 2018.

Dioli, M. 2020. Dromedary (Camelus dromedarius) and Bactrian camel (Camelus bactrianus) crossbreeding husbandry practices in Turkey and Kazakhstan. An in-depth review. Pastoralism 10: 6 https://doi.org/10.1186/s13570-020-0159-3.

Dörrie, H. 1956. Drei Texte zur Geschichte der Ungarn und Mongolen: Die Missionsreisen des fr. Julianus O.P. ins Uralgebiet (1234/5) und nach Russland (1237): und der Bericht des Erzbischofs Peter über die Tartaren. Göttingen: Vandenhoeck \& Ruprecht.

Dublecz, K. 2011. Állati termékek táplálkozás-élettani szerepe. Pannon Egyetem.

Fábri, Zs.N., L. Varga, and P. Nagy. 2014. A tevetej jellemző tulajdonságai és emberi egészségre gyakorolt jótékony hatásai. XXXV. Óvári Tudományos Nap "A magyar és nemzetközi agrár-és élelmiszer-gazdaság lehetőségei". Nyugatmagyarországi Egyetem, Mezőgazdaság- és Élelmiszer-tudományi Kar, Mosonmagyaróvár, 219-223 [ISBN 978-963-334-194-0].

Hussein, T. 2018. Camel meat consumption trends and its medicinal values: A review. Basic Research Journal of Agricultural Science and Review 6 (3): 15-20 April 2018. ISSN 2315-6880.

Johansson, Karolina. 2008. Salt to ruminants and horses. Uppsala: Swedish University of Agricultural Sciences, Department of Animal Nutrition and Management.

Kamalu, Theodore Nkire, Godwin Chidozie Okpe, and Williams Arustus. 2010. Rumen content characteristics and herbage digestibility of cattle and camel grazing native pasture in a Sahel savanna ecosystem. Animal Research International 7 (2): 1194-1198.

Kretzol, Ferenc. 1953. Jelentés a kislángi kalibriai (villafrankai) fauna feltárásáról. A Magyar Állami Földtani Intézet évi jelentése az 1953. évről, 213-238.

Kretzol, Ferenc. 1959. A csarnótai fauna és faunaszint. A Magyar Állami Földtani Intézet évi jelentése az 1959. évröl, 297-395.

Kubinyi, Ferenc. 1859. Teve és ló. Állat-és Öslénytani, s a magyarok keletröl eljövetelére vonatkozólag történelmi tekintetben. Magyar Akadémiai Értesítő IN.

Laszlo, Gy. 1944. A honfoglaló magyar nép élete. Budapest: Magyar Élet.

Lestyán, Z. 2006. Alumínium-oxid kerámia - acélsurlódó pár érintkezési és hőtani viselkedése száraz súrlódás során. Budapest: Doktori értekezés. Budapesti Müszaki és Gazdaságtudományi Egyetem.

Nagy, P.L., J. Olasz, E. Neparáczki, N. Rouse, K. Kapuria, S. Cano, H. Chen, J. di Cristofaro, G. Runfeldt, N. Ekomasova, Z. Maróti, J. Jeney, S. Litvinov, M. Dzhaubermezov, L. Gabidullina, Z. Szentirmay, G. Szabados, D. Zgonjanin, J. Chiaroni, D.M. Behar, E. Khusnutdinova, P.A. Underhill, and M. Kásler. 2020. Determination of the phylogenetic origins of the Arpád Dynasty based on $Y$ chromosome sequencing of Béla the Third. Eur J Hum Genet 29 (1): 164-172 https://doi.org/10.1038/s41431-020-0683-z.

Reszegi, Zs. 2017. Ejtőernyős ugróruházat I. rész. Haditechnika. LI. évf. 2017/1.
Ritter, Carl. 1847. Die geogr. Verbreit. d. Kamels. "Die Erdkunde" XIII, 609. Rozs, M. 2001. Egy új keratinbontó Bacillus licheniformis törzs izolálása és jellemzése. Doktori értekezés (PhD). Szegedi: Tudományegyetem.

Szalay, Béla. 1918. A magyar teve. A Természet 14 (5-7): 63-69;76-78.

Ortvay Tivadar. 1902. Pozsonyvármegye és a területén fekvő Pozsony, Nagyszombat, Bazin, Modors Szentgyörgy városok állatvilága. Állatrajzi és állatgazdaságtörténeti monográfia. A Pozsonyban 1902. szept. 7-én megnyíló országos mezőgazdasági kiállításalkalmából kiadja Pozsony város anyagi hozzájárulásával Pozsony vármegye közönsége. I. kötet, Állatrajzi rész. Pozsony, Stampfel Károly udvari könyvkereskedő bizományában.

Wenzel, G. 1887. Magyarország mezőgazdaságának története. Budapest: MTA Történelmi bizottsága http://real-eod.mtak.hu/1327/1/09403.pdf.

Yagil, R. 1982. Camels and camel milk. FAO Animal production and Health paper. ISBN 92-5-101169-9

Zibaee, S., S.M. Hosseini, M. Yousefi, A. Taghipour, M.A. Kiani, and M.R. Noras. 2015. Nutritional and therapeutic characteristics of camel milk in children: A systematic review. Electronic Physician 7 (7): 1523-1528 https://doi.org/10.1 9082/1523.

Zoltai, L. 1938. A debreceni viselet A XVI - XVIII. században. Az ENTHNOGRAPHIA Füzetei 8. Budapest.

NET

NET 1 https://julianusbaratai.blog.hu/2019/05/13/magna_hungaria

NET 2 https://www.researchgate.net/publication/323028192_Camels_in_ Europe_A_brief_history_of_camel_hybrids_and_camel_breeding_in_Europe_ over_the_last_1000_years

NET 3 https://www.arcanum.hu/hu/online-kiadvanyok/Brehm-brehm-allatok-vila ga-8CCA/emlosok-115/i-alosztaly-egyhuvelyuek-monodelphia-209/iioregrend-patas-allatok-ungulata-7E8/iii-rend-parosujju-patasok-artiodatyla7E9/masodik-alrend-parnastalpuak-tylopoda-A02/1-tevek-camelus-I-AOC/

NET 4. http://www.mgk.u-szeged.hu/hirek-esemenyek/fokuszban/tevetenyesztes: http://www.mgk.u-szeged.hu/hirek-esemenyek/fokuszban/tevetenyesztes

NET 5 https://www.arcanum.hu/en/online-kiadvanyok/Lexikonok-a-pallas-nagylexikona-2/k-E039/kalap-E1DE/

NET 6 https://sites.google.com/site/hagyomanyesmultidezo/nyilvanos/szotar/ka muka

NET 7 https://en.wikipedia.org/wiki/Camlet

NET 8 https://net.jogtar.hu/jogszabaly?docid=99600053.tv

NET 9 https://www.farmersweekly.co.za/agri-technology/farming-for-tomorrow/ca n-camels-solve-the-sweet-thorn-problem/

\section{Publisher's Note}

Springer Nature remains neutral with regard to jurisdictional claims in published maps and institutional affiliations.

\section{Submit your manuscript to a SpringerOpen ${ }^{\circ}$ journal and benefit from:}

- Convenient online submission

- Rigorous peer review

- Open access: articles freely available online

- High visibility within the field

- Retaining the copyright to your article

Submit your next manuscript at $>$ springeropen.com 